\title{
Development of E-Book Learning Media Based on Problem Solving in the Material of the Human Digestive System
}

\author{
${ }^{1}$ Mahrawi, ${ }^{2}$ Umu Istikomah, ${ }^{3}$ Dwi Ratnasari \\ ${ }^{1,2,3}$ University of SultanAgeng Tirtayasa \\ E-mail Correspondence: ukhtyumuistiqomah@gmail.com
}

\author{
Article Info \\ Article History \\ Received: 26 August 2021 \\ Revised: 06 September \\ 2021 \\ Published: 25 September \\ 2021 \\ Keywords \\ biological learning, $e$ - \\ book, human digestive \\ system, problem solving.
}

\begin{abstract}
This research aims to develop e-book learning media using the professional Flip pdf application based on problem solving in human digestive system materials and to test the feasibility of e-book media developed through validation of Experts and to find out the effectiveness of teacher and student responses. Is a type of research development / Research and development that uses 4D models with stages (define, design, develop and disseminate) in this study only up to the stage of develope.descriptive qualitative research design. E-book as a free variable and human digestive system as a bound variable. The population in the study was 18 students of class XI AL-khairiyah High School 4 Cilegon, school year 2021/2022. Data retrieval and collection techniques are carried out by spreading questionnaires and interviews, data analysis techniques using interpretase scales and likert scales to test the feasibility of ebooks that have been created. The results of the assessment of media experts, obtained a score of $82 \%$ and and expert test material obtained a value of $79 \%$ which falls into the category of feasible while the response test of the student response test obtained a score of $88 \%$ and the teacher board $81 \%$ with a very interesting category, based on the results of the study can be concluded that: e-book human suppression system based on problem solving is suitable for student use in biological learning system materials.
\end{abstract}

(C) 2021 Science Education Study Program FKIP Unisla Lamongan.

Citations: Mahrawi, Istikomah, U., \& Ratnasari, D. (2021). Development of E-Book Learning Media Based on Problem Solving in the Material of the Human Digestive System. Science Education and Application Journal. 3 (2). 75-88.

\section{INTRODUCTION}

Technological advances and the demands of today's era, the need for innovation supporting the learning process that can improve the ability of education in Indonesia, especially innovation in learning media. Learning media is everything that can deliver messages, stimulate thoughts, feelings, attract attention, and the willingness of learners so as to support the learning process (Asyhari and Silvia 2016). Innovation in learning media is very necessary, because it is an important component in a learning, so it can be a source of reference for material delivered by teachers. Until now there have been many learning media both in print and electronic, learning media that support technological progress and facilitate the learning process, such as e-book learning media.

As an answer to the challenges of the times, the use of e-books can support students in the learning process. E-books are electronic learning media created to facilitate students in getting learning resources, according to Yusnimar (2014) e-books can also save paper, in the era of global warming it means that we have supported going green which is still being carried out today.. A student can learn practically with his e-book, its electronic nature can be accessed on mobile phones and in other electronic devices. According to Munadi (2012), there are 3 types of media consisting of audio media, visual media, and audiovisual media E- 
books are arranged with visual and audio media so as not to cause saturation in students in learning. In accordance with the results of Ghofur \& Kustijono (2015), the development of ebooks for students is declared feasible for the Validator Team and practical for learners to use. Biology subject matter is a science that is known to be abstract and difficult to understand, and is directly related to everyday life. So that in the creation of e-books there needs to be media development, which can support the learning process running well.

Biological learning in the material of the human digestive system, directly related to daily life, it requires learners to have problem-solving skills. To make students who are able to answer the challenges of the times and participate in providing solutions and playing a role in society for the problems around them related to the digestive system. E-books based on problem solving are based on examples of problems in students' daily lives, so as to improve the skills of learners, and support the achievement of learning goals. Ulya, Rudibyani, \& efkar (2019) stated, it is known that the problem solving-based learning model is much better and effectively used in the mastery of student materials compared to the medium of ordinary modules. Then, according to 21 st century learning students will be required to have critical thinking and problem solving skills.

Based on the results of the interview on the analysis of needs at Al-Khairiyah High School 4 Cilegon human digestive system falls into the category of being understood with a percentage of approximately $60 \%$, However, in the practice and learning media used very minimal and inadequate, as well as the difficulty of the teacher board to explain other biological materials, seeing the development of technology and the circumstances of the pandemic that is being hit, students tend to learn through electronic media because it is known to be practical and accessible, then there needs to be the development of learning media that support the learning process of learners, the development of e-book learning media has not been done and has not been applied in Al-Khairiyah 4 Cilegon High School. The hope is that there is the development of learning media that can facilitate and support students in getting learning resources, said biology teacher at Al-Khairiyah 4 Cilegon High School.

As explained above, this research aims to develop learning media in the form of problem solving-based e-books. Many previous studies have discussed the development of Ebook learning media on Biology subject matter. However, the difference is that this development research is based on problem solving, which is being hotly discussed in $21 \mathrm{st}$ century education. So that the material content in the e-book will prioritize problem solving, which is combined with high school biology learning. More clearly, the difference between this study and other studies, namely, (Khairinal, Suratno, \& Aftiani, 2021). With the title Flip pdf-Based Professional Learning Media Development To Improve Learning Independence and Interest in Learning for Class X IIS 1 SMA Negeri 2 Sungai Penuh City. the difference is that it is based on a professional flip pdf, and the material discussed is different, later in the study (Wulandari, Abidin, \& Praherdhiono 2019). with the title Infographic E-Book Learning Media Development as Cognitive Strengthening of X MIA Students, the difference with this research is in the subject matter discussed and based on infographics developed, and there are many other studies on e-books with different materials and bases.

This study seeks to develop learning media in the form of E-books to improve students' problem solving skills. The developed learning media is expected to educate students in learning biology material in high school. In addition, through this research, it is hoped that teachers can take advantage of the technology and facilities available at SMA AlKhairiyah 4 Cilegon. Based on this, this study raised the title "Development of problem solving-based e-book learning media on the material of the human digestive system. 


\section{METHODS}

This research was conducted in July 2021 at SMA AL-Khairiyah 4 Cilegon. The subjects of this study were obtained based on data sources from large group trials, 18 students of class XI SMA Al-Khairiyah 4 Cilegon, with 6 male students and 12 female students, born in 2005 with an age range of 16 years. The selection of the number of students was based on Arikunto (2013:254) opinion that the number of respondents for small group trials was between 4-14 people, while for large group trials it is between 15-50 respondent. The subject of this study is high school level xi students who follow the subjects of human digestive system, data collection techniques used in this study, namely by document collection, interviews and observation results. This research is a type of research and development research and development ( $\& \mathrm{D})$, Research is used to produce a particular product and test the feasibility of a particular product using a 4D (4-D) development model. The reasons for choosing the 4D development model include: (a). This development model is specifically used for book development and not for learning design development (b). This development model is arranged sequentially and systematically to make it easier to carry out the media development process. This model is also structured programmatically in an effort to solve learning problems according to the needs of students, It consists of 4 stages including, define, design, develop, and dessiminate (Thiagarajan, Sivasailam, Dorothy, S. Semmel, \& Melvyn 1974). Research design in this research method uses a thiagarajan model (4D) consisting of 4 stages, namely defining, planning stage (design), development stage (develop) and disseminate (spread), Based on suggestions and input from supervisors 1 and 2, this research was carried out only until the develop stage because for the undergraduate level the desiiminate stage had to be carried out for a long time, it was also strengthened by Cristanty (2018) research which carried out research up to the Develop stage of his research with the title Virtual Development, Laboratory on the subject of Excretion System to Improve Biology Learning Outcomes.

The instruments used pre-research are instruments in the form of questionnaires and interviews addressed to learners to find out the interests and needs of learners in learning, especially in e-book learning media and interviews to educators to find out the needs and suitability of the use of e-books in high school students in class XI at Al-khairiyah 4 Cilegon High School, The validators involved in this research are 2 validators, namely 1 lecturer as a material expert test and 1 lecturer as a media expert test, then after the product is finished it will be tested by material expert validators and media expert validators with material expert qualifications from science education lecturers and educational qualifications S2, Material expert validator assessed by Mrs. Prasetianingsih, M,Pd, and media expert validator from Mathematics education lecturer and qualified S2, Media expert validator assessed by Mr. Aan Subhan Pamungkas, M.Pd The instrument in this study used a material validation instrument covering aspects of material coverage aspects, material accuracy aspects, and aspects of conformity with grammar and media expert validation instruments consisting of design aspects, problem solving aspects and e-book characteristics.

The data processing techniques in this study use descriptive analysis techniques. Which provides a description of an object studied through existing sample or population data, processing data used in percentage form with the formula used, namely:

Information:

$\mathrm{P}=$ Percentage number

$\mathrm{F}=$ score obtained

$\mathrm{N}=$ expected maximum score

Then the instrument assessment is carried out by the validation of media experts and material experts, using the likert scale, the likert scale used is that we can see in table 2.1 below. 
Table 2.1 Likert scale

\begin{tabular}{ccc}
\hline Category & Value & Score \\
\hline SB & Excellent & 5 \\
\hline B & Good & 4 \\
\hline C & Enough & 3 \\
\hline K & Less & 2 \\
\hline SK & Very lacking & 1 \\
\hline
\end{tabular}

(Sulistyaningrum, 2017)

Then the students' responses to the e-book were tested by students using a questionnaire instrument with a Likert scale with the following criteria:

Table 2.2 Scoring Rubric Criteria

\begin{tabular}{ccc}
\hline Category & Score & Score \\
\hline SB & Very good & 5 \\
\hline B & Good & 4 \\
\hline C & Enough & 3 \\
\hline K & Less & 2 \\
\hline SK & Very less & 1 \\
\hline
\end{tabular}

The results of the questionnaire data obtained are then presented using the interpretation criteria scale in table 2.3 .

Table 2.3 Interpretation Scale

\begin{tabular}{ccc}
\hline Rating Scale & $\begin{array}{c}\text { Percentage of } \\
\text { Achievement }\end{array}$ & $(\boldsymbol{\%})$ Interpretation \\
\hline 1 & $0 \% \leq \mathrm{P} \leq 20 \%$ & Tidak menarik \\
\hline 2 & $21 \% \leq \mathrm{P} \leq 40 \%$ & Kurang menarik \\
\hline 3 & $41 \% \leq \mathrm{P} \leq 60 \%$ & Cukup menarik \\
\hline 4 & $61 \% \leq \mathrm{P} \leq 80 \%$ & Menarik \\
\hline 5 & $81 \% \leq \mathrm{P} \leq 100 \%$ & Sangat menarik \\
\hline
\end{tabular}

(Sulistyaningrum 2017)

\section{RESULTS AND DISCUSSION}

\section{A. Material expert validation results}

Expert validation of media is intended to test the feasibility in terms of media from the e-book of the human digestive system that has been made; the assessment of the material validator includes aspects of material accuracy, scope of material, and aspects of conformity with grammar with the following assessment details.

Table 3.1 Assessment of Expert Validator Material

\begin{tabular}{clcccc}
\hline No & Aspects & Number of values & Max score & $\%$ & Criterion \\
\hline 1 & $\begin{array}{l}\text { Accuracy Of } \\
\text { Material }\end{array}$ & 23 & 30 & $77 \%$ & Proper \\
\hline 2 & $\begin{array}{l}\text { Material } \\
\text { Coverage }\end{array}$ & 32 & 40 & $80 \%$ & Proper \\
\hline 3 & $\begin{array}{l}\text { Grammatical } \\
\text { Suitability }\end{array}$ & 24 & 30 & $80 \%$ & Proper \\
\hline
\end{tabular}




\begin{tabular}{cc}
\hline Total number & 79 \\
\hline Maximum score & 100 \\
\hline Percentage & $79 \%$ \\
\hline Criterion & Proper \\
\hline
\end{tabular}

Scale interprets of material expert tests:

$\mathrm{P}:$ : $79 / 100 \times 100 \%$

$: 0.79 \times 100 \%$

$: 79 \%$

Based on table 3.1, values are obtained for each aspect, namely aspects of material accuracy with a percentage of $77 \%$ with decent criteria, aspects of material coverage of $80 \%$ with decent criteria and aspects of conformity with grammar with a value of $80 \%$ with decent criteria. The presentation of media validation results is spelled out through the following graph:

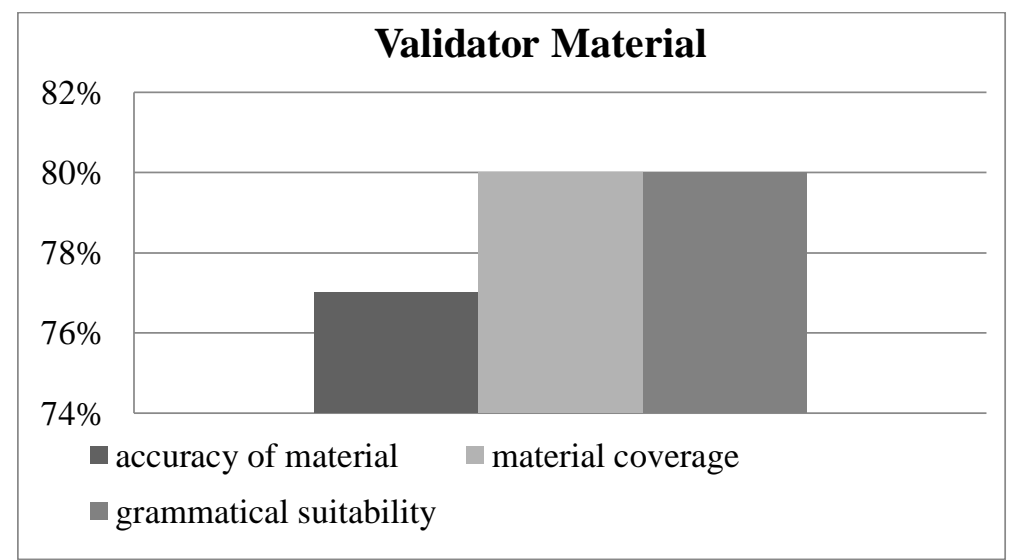

Figure 3.1 Graphs of Material Validator Results

From figure 3.1, it is known that the media e-book human information system in terms of material and aspects that are considered to meet the criteria is feasible. So that it can be tested to students with suggestions must be improved in advance $e$-book according to the repair advice submitted by the validator. The suggestions for improvement are given as follows:

Table 3.2 Improvements to Media Expert Validators

\begin{tabular}{ll}
\hline Repair Section & \multicolumn{1}{c}{ Repair Suggestions } \\
\hline Cover & $\begin{array}{l}\text { 1. Cover or KD, there is no explanation for who this book is for, } \\
\text { whether high school or junior high school students etc., in what } \\
\text { grade }\end{array}$ \\
& $\begin{array}{l}\text { 2. Should not include the identity of the study program, bio } \\
\text { education, etc. }\end{array}$ \\
\hline Concept map & $\begin{array}{l}\text { 3. Concept map is a concept chart that includes the content of the } \\
\text { material, each section must be given a conjunction to explain } \\
\text { the sub-topics of the material }\end{array}$ \\
\hline Material & $\begin{array}{l}\text { 4. The paragraphs used on each page are different, centered or } \\
\text { left and right? }\end{array}$ \\
\hline
\end{tabular}


The appearance of the repair section on the e-book can be seen together as follows:

1) Revision $1 \& 2$

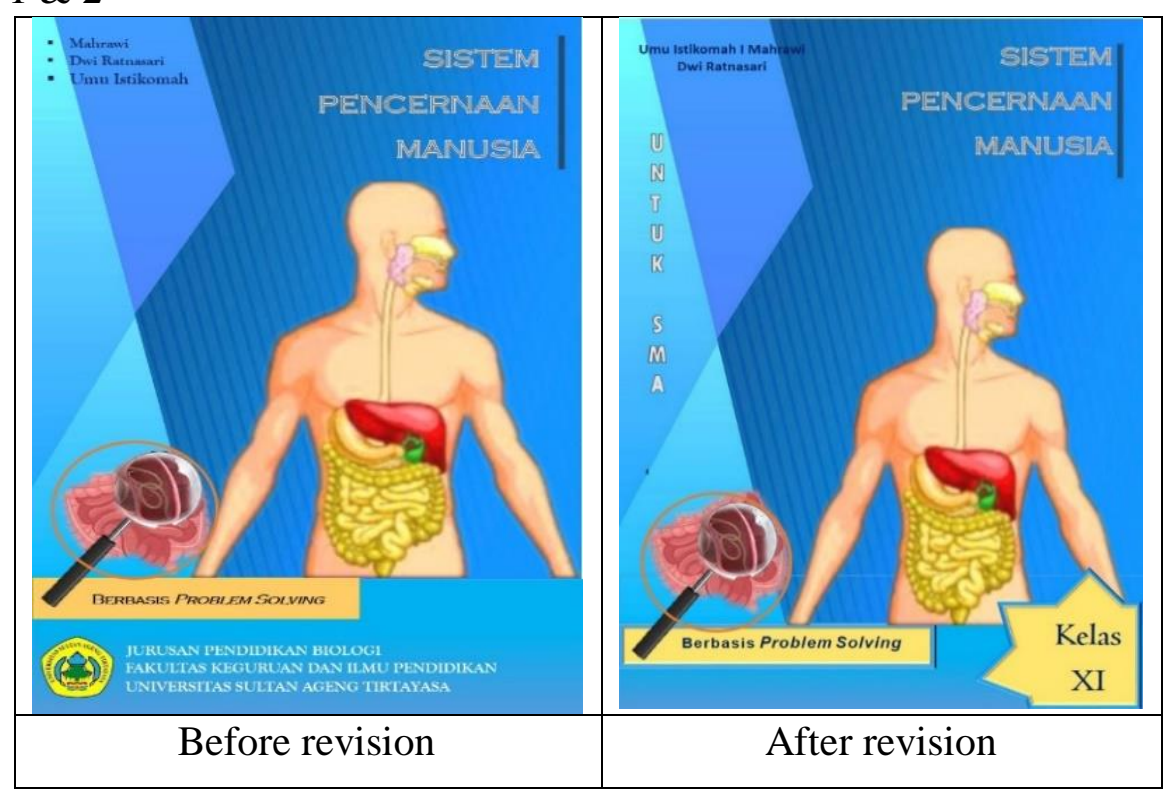

Figure 3.2 Improvement of Material Expert Validator

2) Revision 3

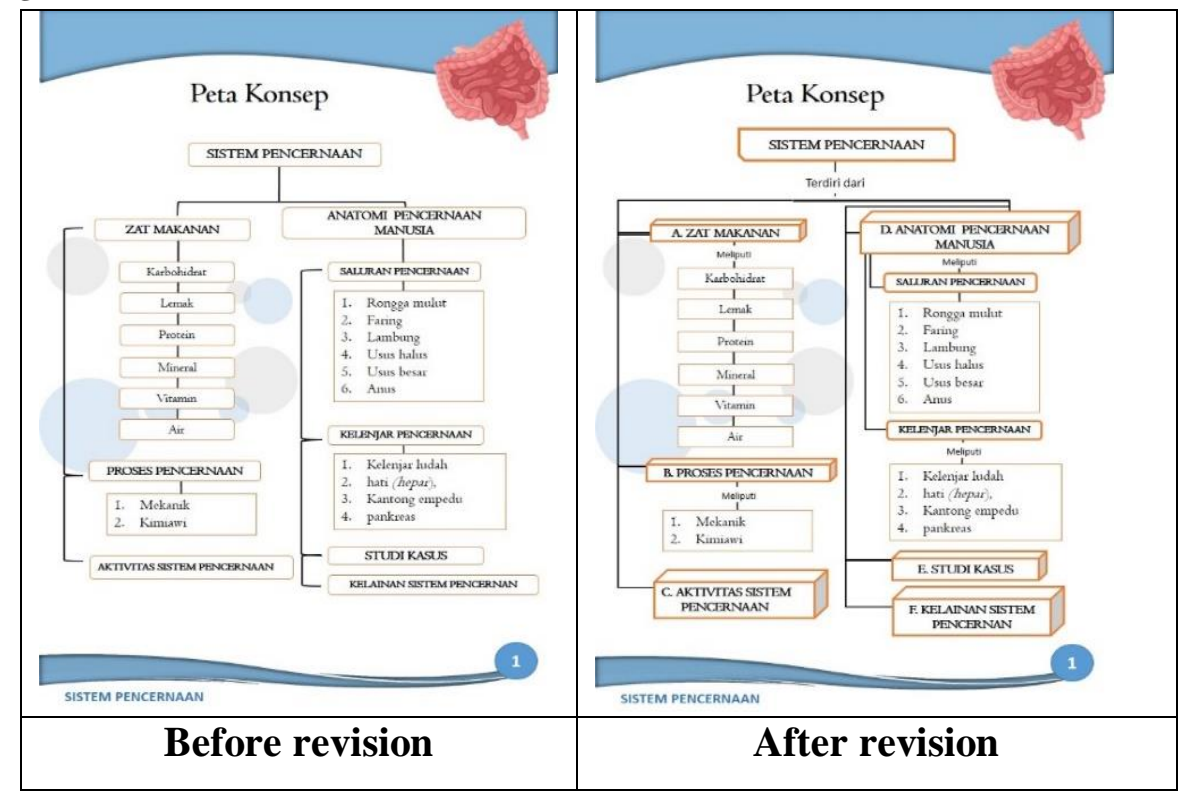

Figure 3.3 Improvements to the Material Expert Validator 
3) Revision 4

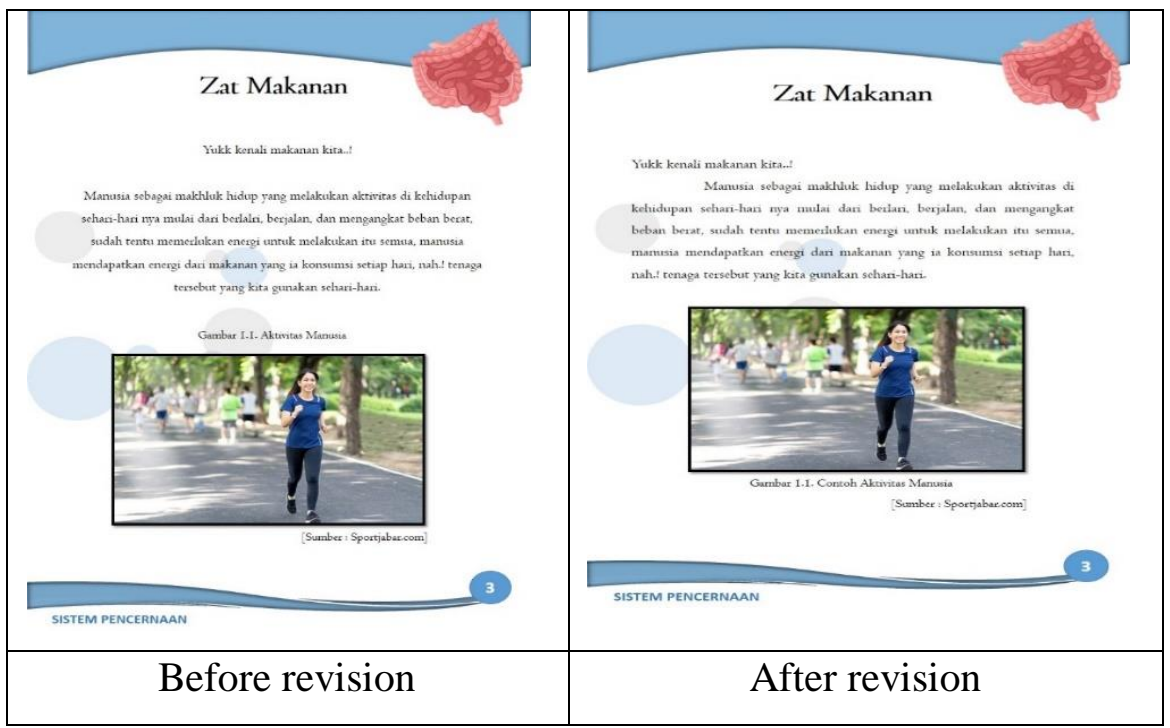

Figure 3.4 Improvements to Media Expert Validators

The results of the validator's suggestions explain that researchers must improve the media before testing it on students and the teacher council.

\section{B. Media Expert Validation Results}

Expert media validation is intended to test the feasibility in terms of media from the $e$ book of the human digestive system that has been made, the assessment of media validators includes aspects of design, aspects of problem solving, and aspects of $e$-book characteristics with the following assessment details:

Table 3.3 Assessment of Media Expert Validators

\begin{tabular}{lllrrl}
\hline No & \multicolumn{1}{c}{ Aspects } & $\begin{array}{c}\text { Number of } \\
\text { values }\end{array}$ & Max score & $\%$ & Criterion \\
\hline 1. & Design & 37 & 45 & $82 \%$ & Very worthy \\
\hline 2. & Problem Solving & 17 & 20 & $85 \%$ & Very worthy \\
\hline 3. & $\begin{array}{l}\text { Characteristics of e- } \\
\text { books }\end{array}$ & 28 & 35 & $80 \%$ & proper \\
\hline Total number & \multicolumn{3}{c}{82} \\
\hline Maximum score & \multicolumn{3}{c}{100} \\
\hline Percentage & \multicolumn{3}{c}{$82 \%$} \\
\hline Criterion & \multicolumn{3}{c}{ Very worthy } \\
\hline
\end{tabular}

Scale Interprets of material expert tests:

$$
\begin{array}{ll}
\mathrm{P} & : 82 / 100 \times 100 \% \\
& : 0.82 \times 100 \% \\
& : 82 \%
\end{array}
$$

Based on table 3.3, the value for each aspect is obtained, namely the design aspect with a percentage of $82 \%$ with very decent criteria, the problem solving aspect of $85 \%$ with very decent criteria and the characteristic aspect of $e$-book with a value of $80 \%$ with decent criteria. The presentation of media validation results is spelled out through the following graph: 


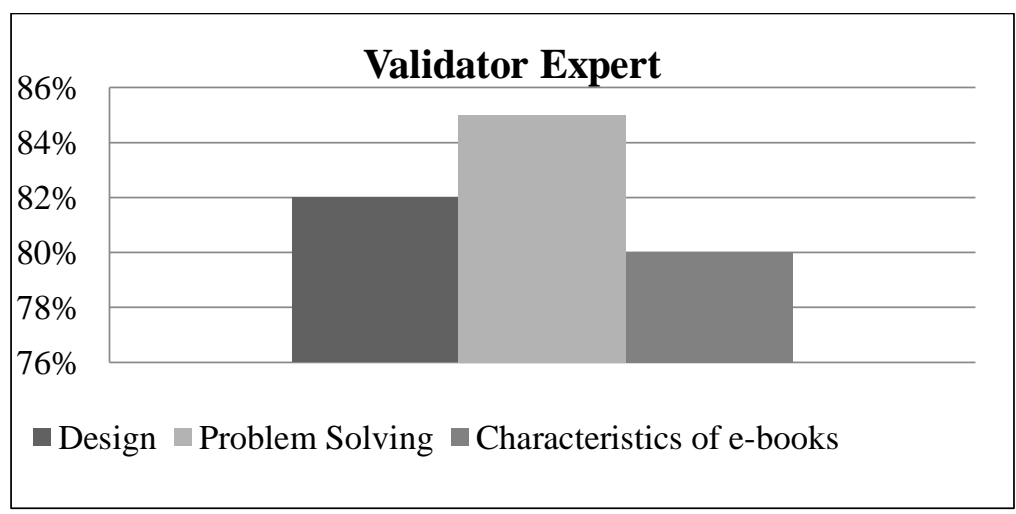

Figure 3.5 Graphic of Media Validator Results

From figure 3.5, it is known that the media e-book system of human information in terms of media and aspects that are valued meet the criteria worthy. So that it can be tested to students with suggestions must be improved in advance $e$-book according to the repair advice submitted by the validator. The suggestions for improvement are given as follows:

Table 3.4 Improvements to Media Expert Validators

\begin{tabular}{ll}
\hline \multicolumn{1}{c}{ Repair Section } & \multicolumn{1}{c}{ Repair Suggestions } \\
\hline Cover & $\begin{array}{l}\text { The cover has not shown who the user of this module is, } \\
\text { middle/high school students } \\
\text { Order of Student Authors, Dospem1, Dospem2 }\end{array}$ \\
\hline Description of e-book & Incomplete module identity, font, page, etc. \\
\hline Evaluation of questions & $\begin{array}{l}\text { For evaluation, it is better to use online quizzes, not } \\
\text { manuals in e-books." }\end{array}$ \\
\hline
\end{tabular}

The appearance of the repair section on the e-book can be seen together as follows:

1) Revision 1

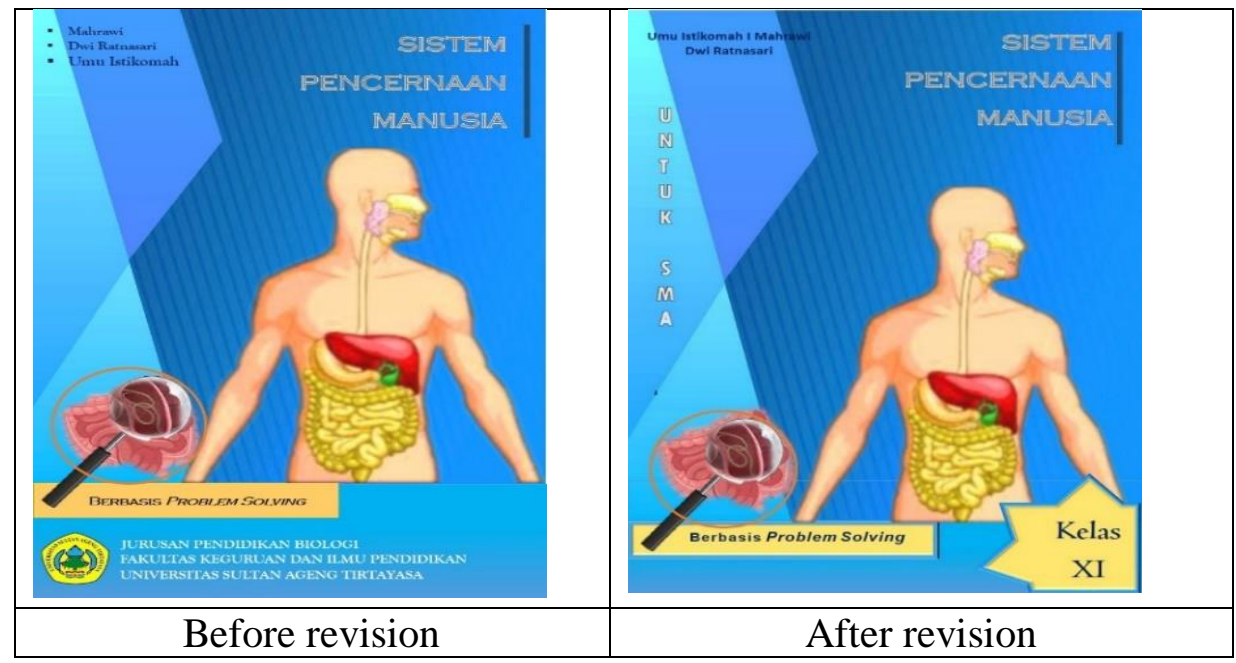

Figure 3.6 Improvements to the Media Expert Validator 
2) Revision 2

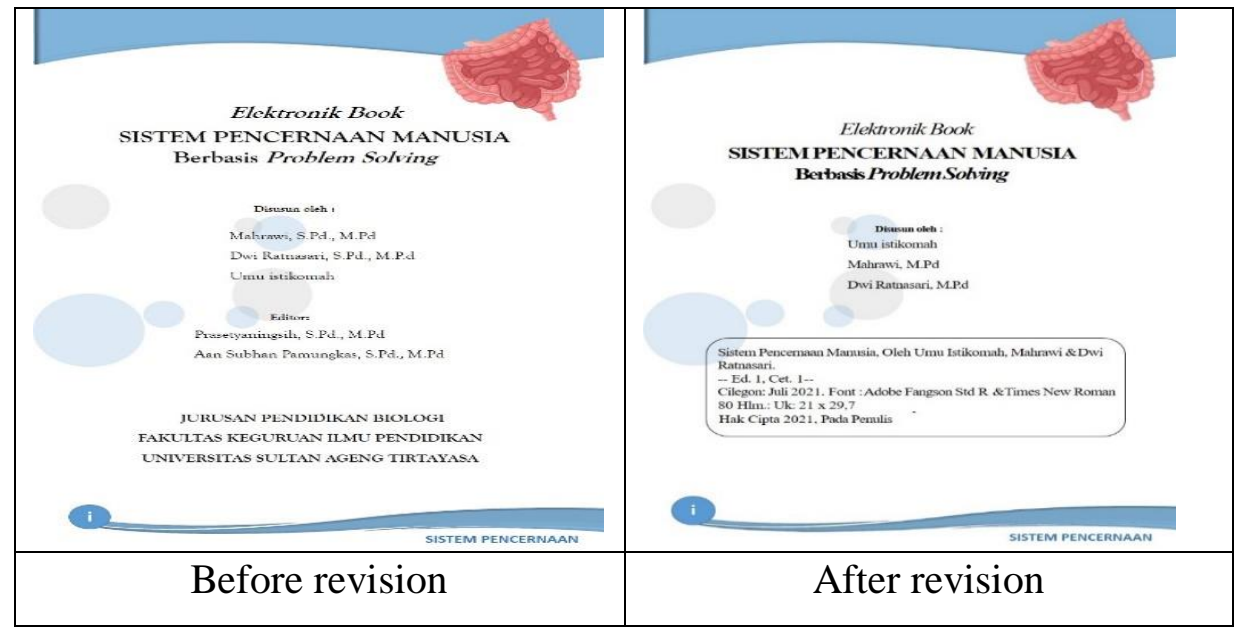

Figure 3.7 Improvements to Media Expert Validators

3) Quiziz

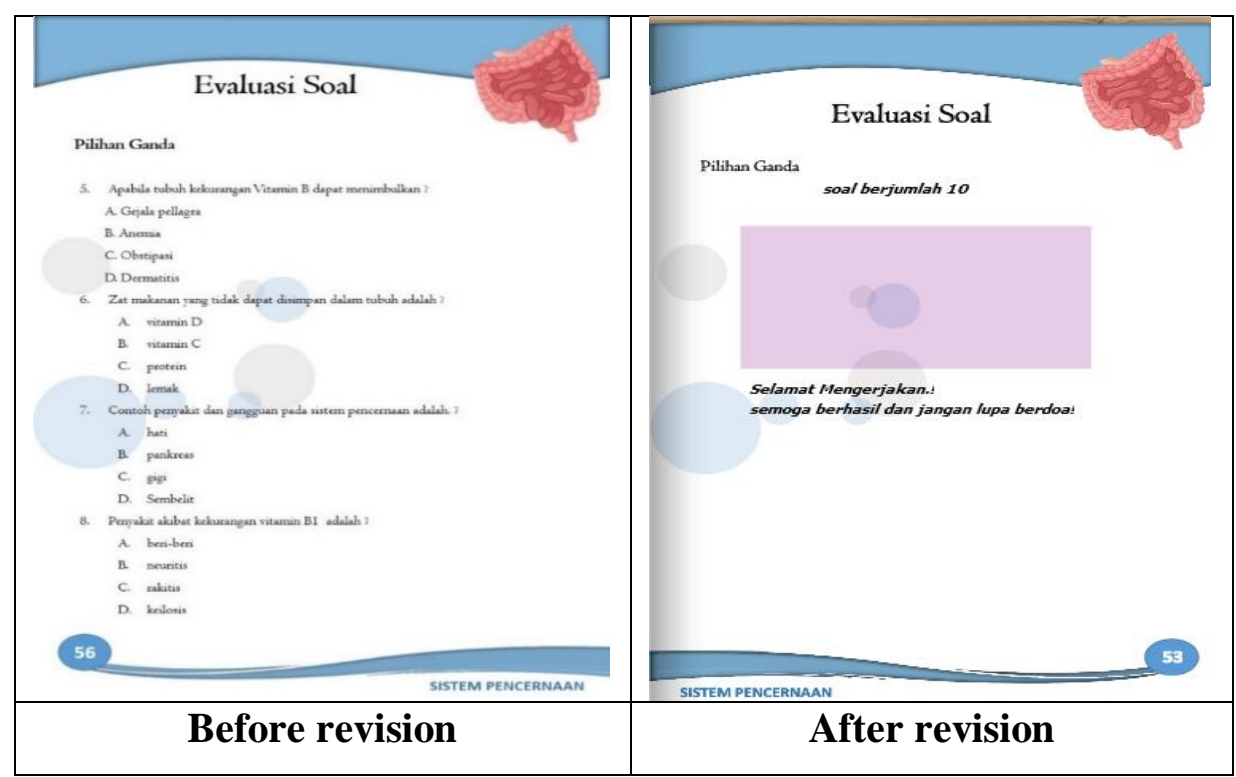

Figure 3.8 Improvements to Media Expert Validators

The results of the validator's suggestions explain that researchers must improve the media before testing it on students and the teacher council.

\section{Test the Response of Educators and Learners}

The response test for biology teachers and students is a limited test at the develop stage, intended to find out the responses from educators and students about the e-book that has been made to the Biology teacher at SMA Al-Khairiyah 4 Cilegon, Mrs. Humaeroh S.Pd on Wednesday, 28 July 2021, and 18 students, namely 12 female students and 6 male students, to find out the attractiveness response test on the e-book that has been made, the student attractiveness test assessment is carried out on Thursday 29 July 2021 face-to-face directly at school. Based on the results of the biology teacher response test obtained a score of $81 \%$ with interesting criteria and the student respo test of 18 students of class XI obtained a percentage of $88 \%$, with the following calculations.

Scale interprets of student response tests:

P : : $1105 / 70 \times 100 \%$

: 1579/18 People 
$: 88 \%$

Scale interprets of biology teacher tests:

P : $: 81 / 100 \times 100 \%$

$: 0.81 \times 100 \%$

$81 \%$

As for the details of the educator response test assessment table as follows:

Table 3.5 Assessment of Educator Response Test

\begin{tabular}{llllll}
\hline No. & \multicolumn{1}{c}{ Aspects } & $\begin{array}{c}\text { Number of } \\
\text { values }\end{array}$ & $\begin{array}{c}\text { Max } \\
\text { score }\end{array}$ & $\%$ & Criterion \\
\hline 1. & $\begin{array}{l}\text { Material Content } \\
\text { Component }\end{array}$ & 33 & 40 & $83 \%$ & $\begin{array}{l}\text { Very } \\
\text { Worthy }\end{array}$ \\
\hline 2. & Serving Component & 28 & 35 & $80 \%$ & Proper \\
\hline 3. & $\begin{array}{l}\text { Aspects Of Language } \\
\text { And Readability }\end{array}$ & 20 & 25 & $80 \%$ & Proper \\
\hline & Total number & \multicolumn{2}{c}{81} \\
\hline & Maximum score & \multicolumn{3}{c}{100} \\
\hline Percentage & \multicolumn{3}{c}{$81 \%$} \\
\hline Criterion & proper \\
\hline
\end{tabular}

Data Source: Processed from the Results of the Assessment of Al-Khairiyah High School Biology Teacher 4 Cilegon

From the interprets calculation image above, it is known that the media $e$-book human analysis system according to the biological teacher's response test from the aspects that are valued, meets very interesting criteria. Here the researchers describe it through the graph.

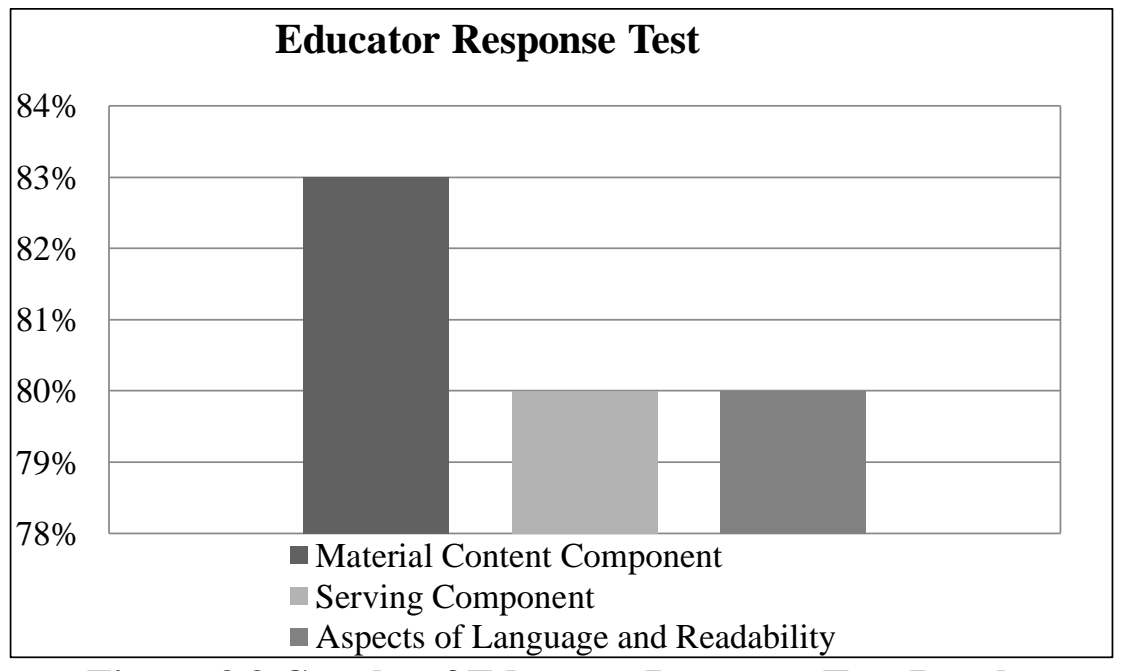

Figure 3.9 Graphs of Educator Response Test Results

The development stage in the study resulted in the assessment of $79 \%$ of material experts, $82 \%$ of media experts and $81 \%$ of practitioner educators, and then a limited test was conducted to 18 learners at Al-Khairiyah High School 4 Cilegon to find out the student's study of $e$-book that had been made. After the learners read and learn the e-book that has been made. The student then fills out the assessment sheet on the Instrument that has been shared with existing statements; the results of the instrument are described as follows: 
Table 3.6 Assessment of Student Response Test

\begin{tabular}{|c|c|c|c|c|c|}
\hline No. & Aspects & $\begin{array}{c}\text { Number of } \\
\text { values }\end{array}$ & $\begin{array}{l}\text { Max } \\
\text { score }\end{array}$ & $\%$ & Criterion \\
\hline 1 & Saryning & 470 & 30 & $87 \%$ & Very worthy \\
\hline 2 & $\begin{array}{l}\text { Serving } \\
\text { Component }\end{array}$ & 311 & 20 & $86 \%$ & Very worthy \\
\hline 3 & Media View & 324 & 20 & $90 \%$ & Very worthy \\
\hline & Total number & \multicolumn{4}{|c|}{88} \\
\hline & Maximum score & \multicolumn{4}{|c|}{70} \\
\hline & Percentage & \multicolumn{4}{|c|}{$88 \%$} \\
\hline & Criterion & \multicolumn{4}{|c|}{ Very worthy } \\
\hline
\end{tabular}

Data Source: Processed from Questionnaire Results Value of students SMA Al-Khairiyah 4 Cilegon

The results of the analysis in table 3.6 obtained the results of the student response test with an assessment of $88 \%$, with the very interesting criteria of the human digestive system ebook has a very interesting category, so it can be used as a biological learning medium in ALKhairiyah High School 4 Cilegon Class XI, while the assessment is spelled out in graph form.

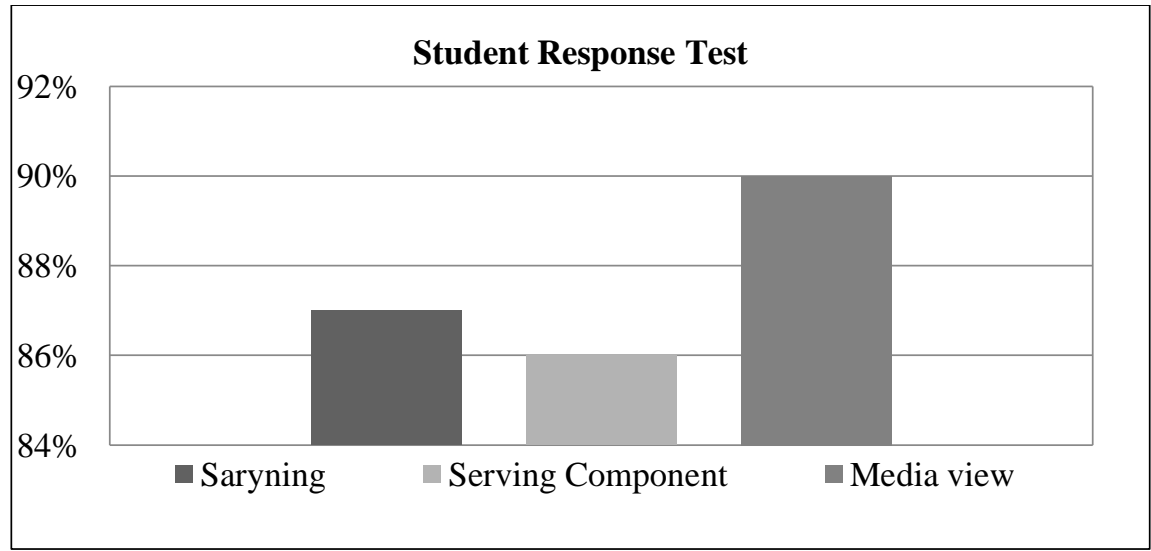

Figure 3.10 Graphs of Student Response Test Results

The development stage based on the evaluation results of material and media experts produces products that are suitable for use and then there will be limited tests to educators and 18 learners to find out the $e$-book's response test that has been made, the results of the $e$ book obtained assessment with a percentage of $88 \%$ with very interesting criteria, and the results of the ministry of biology with a percentage of assessment of $81 \%$ with interesting criteria. After conducting a limited test, it is known that problem solving-based e-books can be used as a learning device on digestive system materials for class XI SMA Al-Khairiyah 4 Cilegon.

The results of media expert tests, material experts, educator response tests and student response tests are presented in the following graph: 


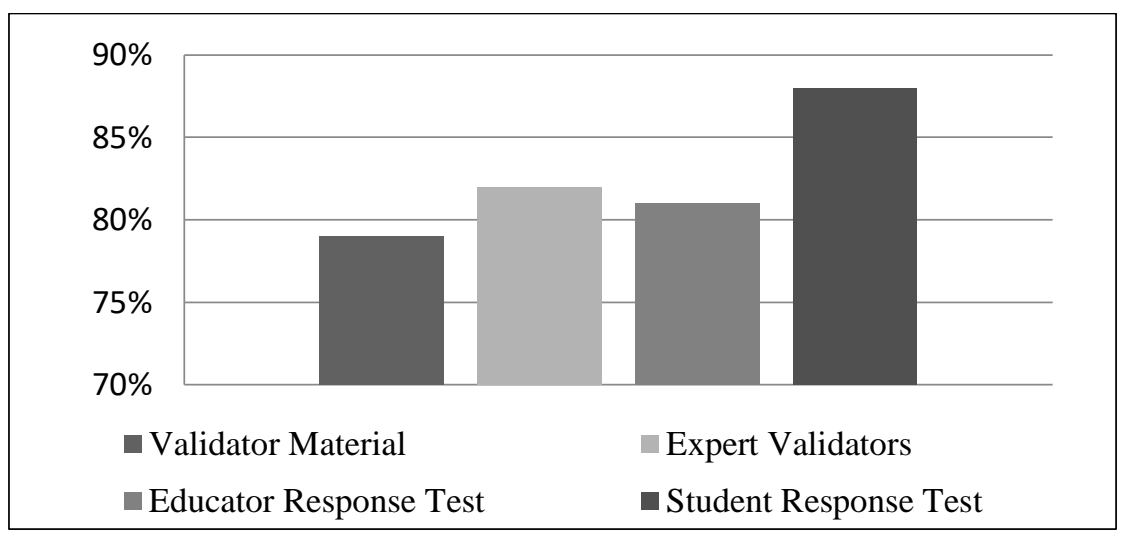

Figure 3.11 Review from Development Stage to Limited Test

The ministry of $e$-book of the human digestive system based on problem solving is with an interesting video display and the preparation and appearance of many images so that it can facilitate in understanding the material. There is music that makes readers become more enthusiastic in reading $e$-books, as well as the application of problem solving in case analysis and problems written based on problems in the community and the surrounding environment. Problem solving uses the stages of problem solving, namely understanding the problem, planning the problem solving, executing the plan, and re-examining. As well as the facilities provided by the professional flip $p d f$ application makes $e$-books more interesting. Its use is easy and can be combined between text, video and images so that it can make it easier for students to understand the material and not saturated or bored in following learning.

Several e-book studies that have also been developed by Wulandari (2008). With the title "Development of e-book-based interactive learning media on digestive system materials for SMP class VIII are concluded that (1). Development of e-book-based interactive learning media in terms of design (various colors, moving images, many menu displays). In terms of material, namely (clearer, accurate and detailed. Then in terms of language the e-book media uses clear, straightforward, and easy to understand language). (2). Feasibility after being validated by validators from 3 expert teams, namely design experts: $88.44 \%$, material experts $89.55 \%$, linguists $88.63 \%$ which means that e-book-based interactive learning media is "very feasible" to be developed. (3). Responses of e-book-based interactive learning media by students obtained the percentage of $93 \%$. Which states "very interesting"? Thus, student responses stated that e-book-based interactive learning media could attract students' attention and interest in learning to increase, the use of language was simpler and easier to understand. Sri Astuti in her research using problem solving-based learning tools can improve students' critical thinking skills (Astuti 2015).

Problem solving-based human digestive system e-Books have several advantages including:

1. This problem solving-based e-book is published in software and online, making it easier for students to access it anywhere and anytime.

2. Problem solving-based e-books are accompanied by audio, video, and visuals to make it easier for students to understand the material.

3. This e-book is prepared based on problems in the community and how to solve them according to the problem solving stages and strengthened by expert opinions regarding the discussion of these problems, making it easier for students to understand the material.

\section{CONCLUSION}

Based on the results of the data analysis it can be concluded that:

1. Based on the expert test of media used a variety of $e$-books composed of audio, visual and video. Based on expert tests the material is easy to understand clearly and includes video 
explanations and medical experts. Based on the response tests of educators and e-book students the human digestive system based on problem solving is very interesting because it is included with video, audio and images, which makes it easier for students to understand the subject matter.

2. Media validation results obtained a value of $82 \%$ which belongs to the category of decent and expert test material obtained a value of $79 \%$ which falls into the category of feasible, based on $e$-book data of human digestive system based on problem solving worth using.

3. Based on the response test biology teacher obtained a score of $81 \%$ with interesting criteria, and student response test with a score of $88 \%$ with very interesting criteria, based on the results of the data obtained it can be concluded that the $e$-book of human digestive system based problem solving is suitable for use in the biological learning process in school, and interesting so that it can help students in learning.

\section{SUGGESTION}

1. For educators

Hopefully this e-book can be used in schools in need, especially at SMA AL-Khairiyah 4 Cilegon.

2. For Students

Hopefully it can be used to increase knowledge

3. For researchers

a) The development of other e-book materials so as to enrich science.

b) It is hoped that there will be a comment column on the developed e-book so that it can provide e-book input.

\section{ACKNOWLEDGMENTS}

Thanks to Allah, the almighty Rahman finally researchers can finish this thesis, to both parents, who never stop praying and helping and thanking those who have provided motivation both moral and material, do not forget also the researcher expressed gratitude and appreciation to:

1. Department of Biological Education Faculty of Teacher Training and Education University of Sultan Ageng Tirtayasa Banten.

2. Mr. Mahrawi, M.Pd as Guidance Lecturer I and Mrs. Dwi Ratnasari, M,Pd as guidance lecturer II who has taken his time and devoted his thoughts to directing the author in completing this thesis.

3. Principal of AL-Khairiyah High School 4 Cilegon and Teacher of Biology of ALkhairiyah 4 Cilegon High School who have given permission to conduct research research and provide convenience to the author to obtain data in the field.

4. Comrades-in-arms, students majoring in biology education class of 2017 who always encourage and go hand in hand in completing this final task.

May Allah (SWT) repay all the good and deeds of all those who have helped. Hopefully this thesis is useful for the development of science. Amin Yarobbalaalamin.

\section{REFERENCES}

Arikunto., \& Suharsimi. (2013). Prosedur Penelitian: Suatu Pendekatan Praktik. jakarta: Rineka Cipta.

Astuti, S. (2015). "Pengembangan Perangkat Pembelajaran Berbasis Problem Solving Model Polya dalam Peningkatan Keterampilan Berpikir Kritis Pokok Bahasan Barisan Bilangan Siswa Kelas IX SMP Negeri 3 Kota Probolinggo.” Pancaran Pendidikan 4:12.

Asyhari., Ardian., \& H. Silvia. (2016). "Pengembangan Media Pembelajaran Berupa Buletin Dalam Bentuk Buku Saku Untuk Pembelajran IPA Terpadu.” Jurnal Ilmiah 
Pendidikan Fisika Al-Biruni 5(1), 3.

Cristanty, N.C. (2018). "Pengembangan Virtual Laboratory Pada Pokok Bahasan Sistem Ekskresi Untuk Meningkatkan Hasil Belajar Biologi." Universitas Jember.

Wulandari. E. (2008). "Pengembangan Media Pembelajaran Interaktif Berbasis E-Book Pada Materi Sistem Pencernaan Untuk SMP Kelas VIII.” Universitas Islam Negeri (UIN) Raden Intan Lampung.

Ghofur., Abdul., \& R. Kustijono. (2015). "Pengembangan E-Book Berbasis Flash Kvisoft Flipbook Pada Materi Kinematika Gerak Lurus Sebagai Sarana Belajar Siswa Sma Kelas X.” Jurnal Inovasi Pendidikan Fisika (JIPF 04(02), 176-180.

Ulya, H., Rudibyani, R.B., T. Efkar. (2019). "Pengembangan Modul Kimia Berbasis Problem Solving Pada Materi Asam Basa Arrhenius.” Jurnal Pendidikan Dan Pembelajaran Kimia 7(1), 129-141.

hiagarajan, L., Sivasailam., Dorothy., S. Semmel., \& Melvyn. (1974). Instructional Development for Training Teachers of Exceptional Children. Bloomington, Indiana: Indiana.

Khairinal, K., Suratno, S., \& R.Y. Aftiani. (2021). "Pengembangan Media Pembelajaran EBook Berbasis Flip Pdf Professional Untuk Meningkatkan Kemandirian Belajar Dan Minat Belajar Siswa Pada Mata Pelajaran Ekonomi Siswa Kelas X Iis 1 Sma Negeri 2 Kota Sungai Penuh.” Jurnal Manajemen Pendidikan Dan Ilmu Sosial 2(1):458-70.

Munadi, Y. (2012). Media Pembelajaran. jakarta: Gaung Persada Press.

Sulistyaningrum., Ayu, D. (2017). "Pengembangan Quantum Teaching Berbasis Video Pembelajaran Camtasia Pada Materi Permukaan Bumi Dan Cuaca." Profesi Pendidikan Dasar 4(2), 154-166.

Wulandari, V., Abidin, Z., \& H. Praherdhiono. (2019). "Pengembangan Media Pembelajaran E-Book Infografis Sebagai Penguatan Kognitif Siswa X MIA." Jurnal Kajian Teknologi Pendidikan 2(1).

Yusnimar. (2014). "E-Book Dan Pengguna Perpustakaan Perguruan Tinggi DI Jakarta.” AlMaktabah 13(1), 34-39. 